\title{
Festival mata air (resistensi budaya masyarakat dalam pelestarian sumber Mata Air Gemulo Desa Bulukerto Kecamatan Bumiaji, Kota Batu)
}

\author{
Tyas Tamara Aldilla, Sukamto, I Nyoman Ruja*, I Dewa Putu Eskasasnanda \\ Universitas Negeri Malang, Jl. Semarang No. 5 Malang, Jawa Timur, Indonesia \\ *Penulis korespondensi, Surel: nyoman.ruja.fis@um.ac.id
}

Paper received: 02-03-2021; revised: 15-03-2021; accepted: 30-03-2021

\begin{abstract}
This research aims to describe the symbolic significance of the Spring Festival in Bulukerto Village, Bumiaji Subdistrict, Batu City as a form of Community Resistance to the construction of The Rayja Hotel. This research uses descriptive qualitative research approaches and types. The methods used in this study are with observation, interview and documentation. The results showed that: 1) Spring Festival is a form of community social movement to reject development that is not environmentally friendly, 2) As a form of gratitude of Bulukerto villagers for the abundance of water for greenness, 3) Increase public awareness of the importance of springs for life.
\end{abstract}

Keywords: spring festival; social movement; symbolic meaning

\begin{abstract}
Abstrak
Penelitian ini bertujuan untuk mendeskripsikan makna simbolik Festival Mata Air di Desa Bulukerto, Kecamatan Bumiaji, Kota Batu sebagai bentuk Resistensi Masyarakat terhadap pembangunan Hotel The Rayja. Penelitian ini menggunakan pendekatan dan jenis penelitian kualitatif deskriptif. Metode yang digunakan dalam penelitian ini dengan observasi, wawancara dan dokumentasi. Hasil penelitian menunjukkan bahwa: 1) Festival Mata Air merupakan bentuk gerakan sosial masyarakat untuk menolak pembangunan yang tidak ramah lingkungan, 2) Sebagai bentuk rasa syukur masyarakat Desa Bulukerto atas berlimpahnya air bagi kehiduapan, 3) Meningkatkan kesadaran masyarakat akan pentingnya sumber mata air bagi kehidupan.
\end{abstract}

Kata kunci: festival musim semi; gerakan sosial; makna simbolis

\section{Pendahuluan}

Air merupakan kebutuhan pokok makhluk hidup baik manusia, hewan maupun tumbuhtumbuhan. Tubuh manusia terdiri dari 55\% sampai 78\% air, tergantung dari ukuran badan (Putri, 2010: 2). Agar dapat berfungsi dengan baik, tubuh manusia membutuhkan antara satu sampai tujuh liter air setiap hari untuk menghindari dehidrasi. Manusia tidak hidup dalam air, tetapi senantiasa mencari tempat tinggal dekat air supaya mudah untuk mengambil air untuk keperluan hidupnya. Kota Batu sebagai kota pariwisata yang terletak di kaki Gunung Arjuna merupakan wilayah penyedia air bagi masyarakat sekitarnya. Salah satu kecamatan yang ada di Kota Batu yaitu Kecamatan Bumiaji yang memiliki sumber mata air kurang lebih 111 titik sumber mata air (BPS Kota Batu: 2014:10) dan salah satunya yaitu Sumber Mata Air Gemulo. Sumber Mata Air Gemulo (Tandon Gemulo) memiliki debit air (Q = 179 lt $/ \mathrm{dt}$ ).

Sumber Mata Air Gemulo dimanfaatkan bagi masyarakat Desa Bulukerto untuk perairan hektaran sawah, daerah perkebunan, Mandi, Cuci, Kakus (MCK) dan keperluan memasak (Saparuddin, 2010: 143). Tidak hanya itu, sumber mata air juga digunakan untuk kebutuhan masyarakat Desa Punten, Desa Bumiaji, Desa Pandan, kebutuhan restorant, hotel, dan tempat penginapan disekitar Sumber Mata Air Gemulo. Kota Batu sebagai pusat pariwisata mengalami 
perubahan pembangunan yang sangat pesat dari tahun ke tahun. Menurut data Badan Pusat Statistik Kota Batu, jumlah hotel dan jasa akomodasi lainnya di Kota Batu pada tahun 2012 adalah 473 perusahaan, naik menjadi 477 pada tahun 2013 dan pada tahun 2014 menjadi 500 perusahaan (BPS Kota Batu, 2014: 22).

Pada tahun 2012 rencana pembangunan dilakukan di Desa Bumiaji Kota Batu oleh pihak hotel The Rayja.. Rencana pembangunan ini ditolak oleh masyarakat Desa Bulukerto, Desa Punten dan Desa Bumiaji. Penolakan ini dikarenakan hotel yang akan dibangun berada di atas lahan konservasi sumber mata air yang hanya berjarak $150 \mathrm{~m}$, hal ini bisa mengakibatkan pencemaran sumber mata air hingga kekeringan. Menurut PP No. 26 Tahun 2008 Tentang Rencana Tata Ruang Wilayah Nasional, dan PP No. 38 tahun 2011 tentang Sungai, serta Peraturan Daerah Kota Batu Nomor 7 Tahun 2011 tentang Rencana Tata Ruang Wilayah Kota Batu tahun 2010-2030 menyatakan bahwa kawasan mata air adalah kawasan perlindungan setempat dan harus dilindungi dalam kisaran radius sempadan mata air yang berjarak 200 (dua ratus) meter.

Alasan masyarakat melakukan penolakan tidak hanya itu saja, tetapi banyaknya keganjalan dalam sosialisasi kepada masyarakat yaitu pihak hotel melakukan sosialisasi hanya dengan pihak-pihak yang pro dengan pembangunan hotel serta tidak terkena dampak dari pembangunan. Adminitrasi dalam pembangunan yaitu perizinan pembangunan hotel yang tidak menyertakan izin Analisis Mengenai Dampak Lingkungan (AMDAL) dan hanya menyertakan perizinan pemerintah Kota Batu. Surat izin diantaranya dokumen upaya pengelolaan ligkungan hidup dan upaya pemantauan lingkungan hidup (UKL-UPL), izin peruntukan tanah dan izin mendirikan bangunan (IMB).

Adanya konflik tersebut, pada Februari 2012 masyarakat Desa Bulukerto membentuk sebuah Forum Masyarakat Pecinta Mata Air (FMPMA). Sebuah gerakan sosial untuk menolak pembangunan Hotel the Rayja. Gerakan sosial menurut Tarrow (2011: 7) digunakan sebagai politik perlawanan yang terjadi ketika rakyat biasa yang bergabung dengan kelompok masyarakat yang lebih berpengaruh menggalang kekuatan untuk melawan para elit, pemegang otoritas, dan pihak-pihak lawan lainya. Konteks gerakan sosial ini merupakan tindakan yang didasari politik perlawanan adalah aksi kolektif yang melawan (Gigih: 2016, 33).

Fungsi dari gerakan perlawanan yaitu agar tuntutan masyarakat terpenuhi. Terdapat berbagai gerakan perlawanan yang dilakukan oleh masyarakat Desa Bulukerto melalui gerakan terbuka yaitu aksi demo di depan gedung kecamatan Bumiaji hingga di Gedung Wali Kota Batu, aksi protes yang menghadang jalan raya di depan lahan pembangunan hotel hingga melakukan diskusi dengan berbagai Lembaga Badan Hukum lainnya. Namun, tidak semua gerakan muncul dengan terbuka dan melawan secara terang-terangan. James Scott dalam penelitianya juga mengatakan bahwa perlawanan kolektif juga dapat dilakukan dengan tertutup, tetapi tetap efektif dalam melakukan aksi protes. Dalam konteks ini, salah satu cara yang dilakukan masyarakat Desa Bulukerto melalui aksi penolakan pembangunan hotel The Rayja adalah dengan menggunakan cara yang tidak frontal namun dapat mempengaruhi masyarakat yaitu dengan gerakan sosial-budaya melalui kearifan lokal setempat. Gerakan ini dikemas kedalam kegiatan Festival Mata Air.

Gerakan perlawanan melalui gerakan sosial-budaya menarik untuk diteliti, pasalnya masyarakat lain sering melakukan aksi protes dan melawan menggunakan cara yang frontal, namun masyarakat Desa Bulukerto menggunakan cara yang tertutup namun tetap dapat 
mempengaruhi masyarakat dalam melakukan perlawanan untuk menolak pembangunan Hotel the Rayja. Festival Mata Air tidak hanya digunakan sebagai bentuk perlawanan namun terdapat makna besar di setiap simbol acaranya. Tujuan penelitian ini mendeskripsikan makna simbolik yang ada pada kegiatan Festival Mata Air di Desa Bulukerto, Kecamatan Bumiaji Kota Batu.

\section{Metode}

Pendekatan yang digunakan dalam penelitian (Resistensi Budaya Masyarakat Dalam Pelestarian Sumber Mata Air Gemulo Desa Bulukerto Kecamatan Bumiaji, Kota Batu) adalah pendekatan kualitatif. Pendekatan ini menjelaskan dan menggambarkan tentang kegiatan Festival Mata Air. sebuah penelitian yang mengungkapkan makna dan nilai yang terkandung dalam festival, Mendeksripsikan secara rinci bentuk dari kegiatan Festival Mata Air di Desa Bulukerto. Bahasa dan interaksi masyarakat terhadap lingkungannya dikaji lebih mendalam.

Kehadiran peneliti dalam penelitian sangat diperlukan dan berperan penting dalam keseluruhan penelitian yaitu sebagai instrumen kunci (key instrument). Penelitian telah dilaksanakan sejak Festival Mata Air dilaksanakan pada Oktober 2016 hingga bulan Maret 2017. Peneliti secara intensif melakukan kegiatan observasi, wawancara, hingga ikut dalam melakukan kegiatan yang diselenggarakan oleh Forum Masyarakat Pecinta Mata Air (FMPMA).

Penelitian ini menggunakan dua sumber data yaitu sumber data primer dan sekunder. Sumber data primer dapat diperoleh melalui observasi secara langsung dan melakukan wawancara langsung kepada informan yang berada di lapangan. Sumber data sekunder merupakan data yang diperoleh secara tidak langsung di lapangan. Sumber data dapat di dapatkan dari studi pustaka berbagai rujukan seperti buku, jurnal, majalah, koran dan arsip yang mendukung dalam topik pembahasan dalam penelitian dan studi dokumentasi berupa foto dan video.

Teknik pengumpulan data pada penelitian ini menggunakan purposive sampling. Purposive sampling adalah teknik yang digunakan dalam peneliti untuk pengambilan sampel sumber data dengan pertimbangan, agar memudahkan peneliti untuk mencari sumber informan yang memiliki pengetahuan luas dan terpercaya (Herdiansyah, 2010: 106). Analisis data menggunakan Milles and Huberman dimana menggunakan tiga alur kegiatan yang terjadi secara bersamaan yaitu: pengumpulan data, reduksi data, penyajian data, penarikan kesimpulan / verifikasi.

\section{Hasil dan Pembahasan}

\subsection{Festival Mata Air Dan Makna Simbolik}

Festival Mata Air merupakan kegiatan yang dilakukan masyarakat Desa Bulukerto sejak tahun 2012. Sebelum dinamakan Festival Mata Air, kegiatan ini bernama Selametan Sumber Umbul Gemulo. Pergantian nama menjadi Festival Mata Air digunakan masyarakat untuk melindungi Sumber Mata Air Gemulo dari berbagai ancaman pembangunan yang tidak memperhatikan lingkungan. Kegiatan Festival Mata Air efektif digunakan sebagai aksi penolakan melalui berbagai aksi kampanye untuk membentuk kesadaran masyarakat dalam melestarikan sumber mata air dan mengingatkan kepada masyarakat lain akan pentingnya sumber mata air bagi kehidupan. Melalui gerakan budaya, masyarakat bebas berkespresi dalam menampilkan berbagai kesenian. Sekaligus memudahkan masyarakat menerima pesan protes yang disuarakan. 


\subsection{Bentuk Kegiatan Festival Mata Air di Desa Bulukerto Kecamatan Bumiaji}

Festival Mata Air dilaksanakan sejak tahun 2012 dan dilakukan secara rutin setiap tahun di bulan Suro. Pengulangan kegiatan festival setiap tahun dilakukan agar mencapai tujuan yang diinginkan yaitu membentuk kesadaran masyarakat akan pentingnya sumber mata air. Menurut pendapat Smith (2016: 67) bahwa festival umumnya dilakukan terus menerus dan berkelanjutan agar tujuan yang diinginkan bisa tercapai sehingga menjadi budaya dalam masyarakat.

Festival Mata Air terus mengalami perkembangan setiap tahunya sesuai dengan perkembangan zaman. Hal ini dilakukan agar masyarakat tidak mengalami kebosanan. Menurut Leksono (2014: 15) kegiatan yang dilakukan berulang-ulang dapat menimbulkan kebosanan dan hilangnya minat seseorang. Oleh karena itu, perlu inovasi baru untuk mengembangkan kegiatan Festival Mata Air. Dalam kegiatan tersebut terdapat dua kegiatan yaitu kegiatan inti dan kegiatan hiburan.

Kegiatan inti merupakan kegiatan yang tidak dapat diubah selama Festival Mata Air. Kegiatan tersebut bernama selametan Sumber Mata Air Gemulo. Geertz (1959: 17) mengatakan bahwa selametan menurut orang jawa dilakukan agar terhindar dari roh-roh halus yang menganggu. Selametan juga digunakan masyarakat sebagai bentuk rasa syukur terhadap pemberian air yang melimpah untuk kebutuhan sehari-hari. Kedua yaitu kegiatan hiburan yang dilakukan setelah kegiatan Sumber Mata Air Gemulo. Pada tahun 2012 Festival Mata Air dimeriahkan oleh kesenian bantengan, tahun 2013-2014 di isi pertunjukan wayang, pada 2015 di isi kegiatan arak-arakan dan pada tahun 2016 di isi dengan diskusi lingkungan hidup.

Festival Mata Air dilaksanakan setiap bulan Suro dikarenakan masyarakat menganggap bahwa bulan Suro adalah bulan yang sakral. Hal ini dijelaskan oleh Sholikhin (2009: 25) bahwa adanya keutamaan bulan suro dipandang sebagai salah satu bulan yang mengandung banyak keutamaan. Penanggalan bulan Suro digunakan oleh Masyarakat Jawa Islam yang menganggap bulan yang dimuliakan oleh Tuhan, sehingga banyak keutamaan yang didapat. Maka pada bulan Suro, masyarakat Jawa memperingati bulan ini secara besar-besaran. Pada masyarakat Desa Bulukerto juga menggunakan momentum bulan Suro untuk mengadakan Festival Mata Air.

\subsection{Makna Simbolik Kegiatan Festival Mata Air Desa Bulukerto, Kecamatan Bumiaji Kota Batu}

Festival Mata Air merupakan kegiatan yang memiliki banyak simbol. Leluhur masyarakat Desa Bulukerto meninggalkan nilai-nilai kehidupan dari berbagai simbol yang ada pada kegiatan Festival Mata Air. Sifat orang jawa menurut Endraswara (2010: 25) biasanya muncul dalam usaha mendidik atau menyampaikan gagasan-gagasannya kepada orang lain tidak "terus terang", melainkan menggunakan simbol atau lambang budaya. Herusatoto (1984:1) juga menjelaskan bahwa bangsa Jawa menggunakan simbol-simbol atau lambanglambang sebagai sarana dan media dalam menitipkan pesan-pesan atau nasihat bagi bangsanya.

Menurut Wardani (2010: 8) Simbol merupakan sebuah pusat perhatian yang tertentu, sebuah sarana komunikasi dan landasan pemahaman bersama. Salah satu simbol dalam 
Festival Mata Air yaitu selametan Sumber Mata Air Gemulo yang digunakan masyarakat sebagai sarana untuk menyampaikan makna, nasihat dan pesan hidup. Makna dari selametan Sumber Umbul Gemulo merupakan bentuk rasa syukur masyarakat Desa Bulukerto kepada Tuhan atas sumber mata air yang melimpah untuk kebutuhan hidup bahkan mengairi sawah dan perkebunan. Hal ini sejalan dengan Endraswara (2006: 223) yang mengatakan bahwa ragam simbol dalam ritual selalu mengacu pada hubungan antara manusia dengan Tuhan yang bersifat vertikal.

Selametan Sumber Umbul Gemulo identik dengan uri-uri, nasi kenduren dan ayam tulak. Uri-uri merupakan salah satu sesaji yang didalamnya terdapat kelapa tua, telur, serit kayu, tali rawe, kaca, rokok klobot, minyak wangi, nginang, kemenyan dan air ketan hitam. Makna yang terkandung dalam uri-uri antara lain kelapa tua (cikalan) simbol dari seorang yang pertama kali ada. Telur yang didalamnya ada warna kuning merupakan simbol ning yaitu harus selalu dekat dengan Tuhan. Tali rawe bermakna manusia harus taat dengan aturan yang ada di masyarakat. Kaca merupakan simbol berbalik. Rokok bermakna rasa. Air ketan hitam (badek) yang artinya keyakinan dalam melakukan sesuatu dan kemenyan merupakan bentuk kekhusukan masyarakat dalam meminta sesuatu kepada Tuhan. Hal ini sesuai dengan Sholikhin (2010: 31) bahwa Kemenyan digunakan masyarakat Jawa Islam sebagai bagian dari penyembahan kepada Tuhan secara khusyuk.

Simbol dalam selametan Sumber Umbul Gemulo selanjutnya adalah ayam tulak. Tulak artinya tolak, jadi ayam tulak merupakan simbol dari menolak balak. Ayam tulak digunakan masyarakat dalam dua bentuk, pertama sebagai lauk dalam nasi kenduren tetapi hanya bagian sayap, hati dan dan kepala. Kedua digunakan untuk dihanyutkan kedalam aliran sumber mata air. Terakhir, yaitu Nasi Kenduren yang dimakan bersama-sama setelah acara kegiatan selesai. Nasi kenduren merupakan simbol dari kebersamaan tanpa membeda-bedakan status, agama, ras dan suku. Geertz, (1959: 17) dalam penelitianya juga mengungkapkan bahwa disetiap acara selametan semua orang diperlakukan sama, tak seorang pun merasa lebih rendah dari yang lain dan tidak ada seorang pun mempunyai keinginan untuk memencilkan diri dari orang lain.

Kegiatan hiburan yang dilakukan pada Festival Mata Air juga memiliki makna tersendiri. Pertama, Kegiatan bantengan memiliki makna sebagai simbol dari perlawanan rakyat, sesuai dengan pernyataan Desprianto (2013: 152) bahwa lahirnya seni Bantengan merupakan bentuk perlawanan rakyat terhadap pemerintahan kolonial Belanda. Kedua, pertunjukan wayang yang digunakan masyarakat sebagai media informasi terkait pentingnya menjaga kelestarian lingkungan, khususnya di lingkungan di Kota Batu. Fajrie, (2013: 219) menyatakan bahwa setiap pertunjukan seni wayang, cerita yang terkandung di dalamnya merupakan simbol dari kehidupan yang berperan penting dalam membangun kehidupan berbangsa dan bernegara. Ketiga, Arak-arakan merupakan simbol gotong royong, dimana masyarakat bekerja sama dalam mensukseskan kegiatan Festival Mata Air, karena kegiatan tersebut adalah bentuk rasa syukur masyarakat Desa Bulukerto atas melimpahnya Sumber Mata Air. Terakhir, yaitu diskusi lingkungan dan parade band yang digunakan masyarakat untuk menarik minat anak muda dalam melestarikan sumber mata air. 


\subsection{Nilai-Nilai Kearifan Lokal Masyarakat Desa Bulukerto dalam Melestarikan Sumber Mata Air Gemulo}

Definisi kearifan lokal mengandung beberapa konsep, yaitu kearifan lokal adalah sebuah pengalaman panjang, yang diendapkan sebagai petunjuk perilaku seseorang, kearifan lokal tidak lepas dari lingkungan pemiliknya dan kearifan lokal itu bersifat dinamis, lentur, terbuka, dan senantiasa menyesuaikan dengan zaman (Istiawati, 2016: 6). Menurut Wagiran (2012: 330) Kearifan lokal memiliki dua ruang lingkup yaitu gagasan, pemikiran, akal budi yang bersifat abstrak dan kearifan lokal yang berupa hal-hal konkret.

Ruang lingkup dalam penelitian ini pertama kearifan lokal yang ada di masyarakat Desa Bulukerto merupakan gabungan dari kearifan tradisional dan kearifan modern. Hal ini karena kearifan tradisional dapat dilihat dari nilai yang terkandung pada selametan sumber umbul gemulo, sedangkan kearifan kini dapat dilihat dari kegiatan hiburan dalam Festival Mata Air. Kedua benda-benda artefak yang bermakna simbolik dapat dilihat dari rangkaian kegiatan Festival Mata Air yang memiliki makna tersendiri. Melalui kearifan lokal yang ada pada masyarakat Desa Bulukerto, terdapat berbagai nilai yang dapat dijadikan pedoman hidup bagi semua masyarakat.

Adapun nilai-nilai kearifan lokal yang ada pada acara festival mata air yaitu 1) Nilai Religius tercermin dalam selametan sumber umbul gemulo sebagai simbol rasa syukur masyarakat. Sholikin (2010: 44) menjelaskan bahwa inti dari selametan adalah bersyukur kepada Allah dan menyampaikan permohonan kepada Allah. 2) Nilai moral masyarakat tercermin dalam kesadaran tentang hakikat hidup. Melalui Festival Mata Air, masyarakat sadar bahwa alam semesta memiliki satu kesatuan yang utuh dan saling bergantung. 3) Nilai gotong royong dapat dilihat dari masyarakat bekerja sama dari tahap persiapan hingga acara penutup tanpa membedakan pangkat dan kedudukan dalam mensukseskan kegiatan Festival Mata Air. 4) Peduli lingkungan yang tercermin pada pesan roh leluhur untuk selalu menjaga lingkungan alam dengan tidak meninggalkanacara selametan, bersih sumber umbul gemulo serta penanaman seribu pohon. 5) Cinta tanah air yang tercermin dalam kegiatan arak-arakan yang didalamnya terdapat patung garuda serta tari sapu pancasila. melalui simbol tersebut merupakan bentuk rasa nasionalisme dan cinta tanah air yang diungkapkan masyarakat serta merupakan bukti nyata bahwa budaya itu khas budaya Indonesia. 6) Sikap toleransi dapat dilihat dalam masyarakat Desa Bulukerto yang mengikuti kegiatan Festival Mata Air, dari berbagai golongan, ras, agama dan kedudukan. Hal ini yang dapat menciptakan kerukunan dalam masyarakat.

\section{Simpulan}

Festival Mata Air merupakan kegiatan yang dilakukan masyarakat Desa Bulukerto dalam mempertahankan Sumber Mata Air Gemulo. Sebelum bernama festival mata air, kegiatan ini bernama selametan sumber umbul gemulo. pergantian nama menjadi festival mata air disebabkan oleh banyaknya ancaman pembangunan yang tidak memperhatikan lingkungan sumber Mata Air Gemulo. festival ini digagas oleh masyarakat Desa Bulukerto yang tergabung dalam Forum Masyarakat Pecinta Mata Air, sebuah gerakan sosial-budaya untuk menolak pembangunan yang berada di sumber mata air gemulo. Kegiatan Festival Mata Air telah mengalami perkembangan setiap tahunnya dengan berbagai variasi sesuai dengan trend zamanya. Namun, terdapat kegiatan yang tidak dapat diubah selama Festival Mata Air yaitu selametan Sumber Umbul Gemulo. Festival ini dilakukan setiap satu tahun sekali pada bulan 
Suro yang dipercaya memiliki banyak keutamaan. Festival Mata Air merupakan kegiatan yang memiliki berbagai makna. Makna tersebut digunakan masyarakat untuk menyampaikan nasihat dan pesan hidup bagi generasi selanjutnya. Makna tersebut merupakan 1) sebagai bentuk rasa syukur masyarakat Desa Bulukerto atas berlimpahnya air bagi kehiduapan, 2) sebagai bentuk penolakan masyarakat pada pembangunan yang tidak ramah lingkungan, 3) meningkatkan kesadaran masyarakat akan pentingnya sumber mata air bagi kehidupan. Melalui makna yang terkandung dalam kegiatan tersebut, terdapat berbagai nilai kearifan lokal yaitu nilai religius, nilai moral, nilai budaya, peduli lingkungan, toleransi, nilai gotong royong dan hiburan yang dapat dijadikan pedoman hidup bagi masyarakat.

\section{Daftar Rujukan}

Arrow, S. (2009). Power In Movement. New York: Cambridge University Press.

Badan Pusat Statistik (BPS) Kota Batu. (2014). Kota Batu dalam Angka tahun 2014. Batu: BPS Kota Batu.

Endraswara, S. (2006). Mistik Kejawen. Yogyakarta: Narasi.

Endraswara, S. (2010). Falsafah Hidup Orang Jawa. Yogyakarta: Cakrawala.

Fajrie, N. (2013). Media Pertunjukan Wayang Untuk Menumbuhkan Karakter Anak Bangsa. Jurnal Penelitian Humaniora, (Online), (https://publikasiilmiah.ums.ac.id/bitstream/handle/11617/3486/12_Media_Pertunjukkan_Wayang.pdf?sequence=1), diakses 31 Juli 2017.

Geertz, C. (1959). The Religion of Java. Chicago University Press.

Gigih, P. (2016). Gerakan Masyarakat Penyelamat Sumber Mata Air Gemulo, Batu (Kasus Pembangunan Hotel The Rayja). Yogyakarta: UGM.

Herdiansyah, H. (2010). Metodologi penelitian kualitatif untuk ilmu-ilmu sosial. Yogyakarta: Salemba Humanika.

Herusatoto, B. (1984). Simbolisme dalam budaya Jawa. Yogyakarta: PT. Hanindita.

Istiawati, N. (2016). Pendidikan Karakter Berbasis Nilai-Nilai Kearifan Lokal Adat Ammatoa Dalam Menumbuhkan Karakter Konservasi. Jurnal Cendekia, (online), 10 (1): 1-18 (Web: cendekia.pusatbahasa.or.id), diakses 10 juni 2017.

Leksono, H. (2014). Kebosanan Kerja: Peningkatan Stres Dan Penurunan Kinerja Karyawan Dalam Spesialisasi Pekerjaan. Jurnal JIBEKA, (online), 8 (2): 14-18 (http://lp3m.asia.ac.id/wp-content/uploads/2014/09/Hendi-Suryo-Leksono-JIBEKA-vol-8-no-2-Agustus-2014.pdf), diakses 29 Juli 2017.

Melanie Smith, Macleod, Nicola and Robetson, Margareth. (2010). ey Concept in Tourist Studies. London: SAGE Publication Ltd.

Milles and Huberman. (1992). Analisis Data Kualitatif: Buku tentang sumber tentang metode-metode baru. Terjemahan Tjejep Rohendi Rohidi. Jakarta: UI Press.

Peraturan Daerah Kota Batu NO. 7. (2011). Tentang Tata Ruang Wilayah Kota Batu Th. 2010- 2030.

PP No. 26 Th. 2008 . (2008). Tentang Rencana Tata Ruang Wilayah Nasional.

PP No. 38 Th. 2011 . (n.d.). Tentang Sungai.

Putri, R. (2010). Perbedaan asupan cairan berdasarkan kelompok umur, jenis kelamin dan tipe darah pada penduduk di pulau Sulawesi. Jakarta: Prodi Ilmu Gizi, UEU.

Ruri, D. (2013). Kesenian Bantengan Mojokerto (Kajian Makna Simbolik dan Nilai Moral). Jurnal Pendidikan Sejarah, 150-163.

Saparuddin. (2010). Pemanfaatan Air Tanah Dangkal sebagai sumber air bersih. Journal Smartek, (online), 8 (2): 143-152, (downloadportalganda.org).

Sholikhin, M. (2009). Misteri Bulan Suro (Perspektif Islam Jawa). Jakarta: Penerbit NARASI.

Wagiran. (2012). Pengembangan Karakter Berbasis Kearifan Lokal Hamemayu Hayuning Bawana(Identifikasi Nilai-nilai Karakter Berbasis Budaya). Jurnal Pendidikan Karakter, (online), 2 (3): 329-339, , (http://staffnew.uny.ac.id/upload/132297916/penelitian/Hamemayu+Hayuning+Bawana.pdf), diakses 10 juni 2017. 
Jurnal Integrasi dan Harmoni Inovatif Ilmu-Ilmu Sosial (JIHI3S), 1(3), 2021, 277-284

Wardani, l. (2010). Fungsi, Makna dan Simbol (sebuah kajian teoritik). Surabaya: Makalah disajikan dalam Seminar Jelajah Arsitektur Nusantara, jurusan Desain Interior Fakultas Seni dan Desain Universitas Kristen Petra, Surabaya 10 Oktober. 